\title{
Under a cloud of committees
}

\author{
From Sydney, Peter Pockley updates some \\ recent developments in Australian science policy
}

$\mathbf{T}^{\mathrm{H}}$

HE science-and-politics scene in Australia in the first half of 1977 has been remarkable only for much running on the spot with accompanying huff and puff. The symptoms are characteristic of SIC, the Syndrome of Inquiry and Committee, which, whether caught adventitiously or implanted deliberately, is manifest through a distinct brake on progress.

Those looking for a plot behind every move of the present conservative government might adduce SIC as evidence of a concerted move to downgrade the national science effort, the end result being disastrous attrition of the research dollar through gailoping inflation before any substantive action occurs. But, on unravelling who is doing (or not doing) what among the dozen or so federal government departments with a major stake in science and technology, it is not surprising to find little more than a classic case of uncoordination.

One positive aspect of SIC is the appearance it gives of greater sympathy within the Liberal/Country Party government towards science, notably its applied aspects, than obtained within its Labor predecessor, in spite of the fact that under Labor science policy discussions were more public than before. After 18 months in office, though, the Fraser government's interest is still expressed only by SIC and the maintenance, for the time being, of the status quo. Everyone now expects the funds for science to remain very tight while high inflation $(11-15 \%$, depending on time-scale and assumptions) and high unemployment $(5.5 \%$, the highest since the Depression years) dominate the economic climate. Nonetheless, there are some government in: quiries and committees which have the potential, at least, to affect constructively the course of events.

\section{Breathing space}

Late last year, a three-man Committee of Inquiry was established to look thoroughly into Australia's research colossus, the Commonwealth Scientific and Industrial Research Organisation (CSIRO). The full-time Chairman, seconded for the purpose from the Australian National University, is Professor Arthur Birch, an organic chemist noted for his contribution to the contraceptive pill. The other two members of the committee are a financier and an industrialist. Their appointments caused some tremors that the government was intending, through the inquiry, to commercialise CSIRO by demanding short-term financial benefits from its research.

The final clause of the comprehensive terms of reference for the inquiry required the committee to "examine, report, and make recommendations on the extent to which and the means by which programs of the Organisation could attract revenue both to support the conduct of ongoing or intended research and also in return for results achieved in research".

The inquiry, though, ranges far wider than this. While it was not intended as a mere cost-benefit study of the operations of CSIRO's 37 divisions and 100 -plus operations and $\$ 140$ millionplus budget, the pressure was on the members to come up with an interim report early in the year. The urgency was felt because of the imminence of the retirement in March of CSIRO's Chairman, Sir Robert Price (formerly Dr Jerry $\mathbf{R}$. Price). The inquiry was asked to answer the question of what kind of person is needed to head the organisation, but an organisation that before long would presumably have some new terms of reference from the government as a result of the inquiry's own recommendations, which would have been either tentative or unframed at that time.

The government solved the inquiry's dilemma by appointing, for 12 months only, a new chairman in $\mathrm{Mr}$ Victor Burgmann, a long-standing member of CSIRO's Executive. The inquiry now has some breathing space for its major tasks, on which it was originally expected to report to the Prime Minister by the end of July.

Professor Birch says the inquiry is "not trying to put a few band-aids on CSIRO, but is taking a hard look at the whole set-up-where it fits in between universities and industry, and between Commonwealth and State departments and instrumentalities. While the benefits from cost-benefit analysis of CSIRO's research will be very hard to measure, we are making strenuous efforts to gain a good idea of them."

The Prime Minister showed his close interest in the inquiry by issuing the commission himself and, although CSIRO is responsible under its Act to the Minister for Science, Senator James Webster, the report will go to $\mathrm{Mr}$ Fraser.

Professor Birch says he has no political connections and he hopes the in-
Sorry, for copyright reasons some images on this page may not be available online

Malcolm Fraser, Prime Minister

\section{Sorry, for copyright reasons some images on this page may not be available online}

James Webster, Minister for Science

quiry's recommendations ("not gospel from heaven") will be acceptable to both sides of Parliament, for he sees CSIRO's operations as "lying outside the range of normal party politics". Nevertheless, given the continuing silence of the Labor Party on matters scientific, it is likely that $\mathrm{Mr}$ Fraser will be able to remould CSIRO's terms of reference to his own liking.

\section{Going autonomous}

The longest running stage show in Australian science-the on-again, offagain saga of a science council in various costumes-has at last been concluded with an announcement that the independence, permanence and stability of a statutory authority would be granted to ASTEC, the Australian Science and Technology Council. ASTEC proper, however, still has to await the presentation and passage of legislation through Parliament.

At least ten years of lobbying of successive Prime Ministers and Ministers for Science finally bore fruit when Mr Fraser announced on 19 April that he had accepted, in large measure, the recommendation of the Interim (continued on page 479) 
The federal Inquiry into Education and Training, which is trying to relate post-secondary education and the job market, will also impinge on science, though not directly. Professor Bruce Williams, an economist who is Vice-Chancellor of the University of Sydney, is chairing the Inquiry which is being taken very seriously indeed by the three tiers of universities, colleges of advanced education, and technical and further education.

If the current political cry for 'relevance in education' (that is less unemployment among secondary and tertiary education leavers) has any pull left by the time the Inquiry reports next year, then a reduction in the research and scholarship activity at universities relative to vocationally oriented training is possible. However, the appointment of a resilient university man as chairman is reasonable protection for the university position.

\section{Sorry, for copyright \\ reasons some images on this page may not be available online}

Sïing Spring Observatory (see opposite)

\section{(continued from page 476)}

ASTEC about its continuation*. Mr Fraser's statement is worth quoting at some length:

The functions of ASTEC are to advise the Government on science and technology, including

- the advancement of scientific knowledge and the development and application of science and technology in relation to the national well being;

- the adequacy, effectiveness and overall balance in the national effort in science and technology in Government, industry, education and other sectors of the community;

- the assessment of gaps and overlaps in science and technology in Australia;

- the identification and support of new ideas of science and technology likely to be of national importance;

- the practical development and application of research discoveries and the fostering of technological innovation in industry; and

- the means of improving efficiency in the use of resources related to science and technology.

The Council will have a strategic role in assisting the Government to encourage Australian science and technology to meet the nation's needs and objectives. It will have no executive responsibilties but will be able to advise on operational arrangements.

ASTEC's knowledge and analysis of science and technology will be valuable to many arms of Government. And the Government expects the Council to inform itself and be informed of relevant Government policies and to take into consideration economic and budgetary implications in discharging its functions.

ASTEC will draw on existing Departments and Agencies for the expertise, knowledge and assistance necessary to enable these functions to be discharged effectively. But this will in no way com5 promise the independence of ASTEC.

ASTEC has been charged first with preparing a long-overdue report on the present state of science and technology in Australia. Information about Australia's effort has been so fragmented, particularly in the government arena which dominates national $R \& D$ expenditure, that the very thought of deriving coherent policies from such information boggles the mind. This task may well be measured in years and is almost certain to out-run the life of the present Parliament, which has only 18 more months at the most.

ASTEC is thus unlikely to influence the science funding sections of the August 1977 budget, framing for which is already well advanced (to cries of "horror budget cuts"), and may hardly have sufficient time to influence the 空

$\delta_{\text {* Future Arrangements for an Australian }}$ Science and Technology Council, Report to the Prime Minister by the Interim to the Prime November 1976 (Australian ASTEC, Novernment Publishing Service; 1977).
1978 budget and the present government's final burst of legislation before facing the people again.

As anticipated in earlier reports, the permanent ASTEC reports to the Prime Minister. Its small secretariat is established within the Prime Minister's own Department. That these moves will be popular among scientists and technologists is quite certain. An analysis of the views expressed in submissions to the Interim ASTEC showed that 46 of them favoured ASTEC reporting to the Prime Minister, 6 to a Ministerial Committee, 3 to Cabinet as a whole, 4 'others', and a bare 2 to the Minister for Science. Hardly a resounding vote of confidence in the political clout of the scientists' 'own' Ministry.

The government intends that ASTEC's reports will be made public "unless there are overwhelming reasons in the national interest for not doing so" (in other words, when the security boys cry stop). Meanwhile the Australian Academy of Science, whose influence over government went into a small, temporary decline under Labor, has emerged triumphant with the appointment of its current president, Professor Geoff Badger, as part-time Chairman of ASTEC, and its immediate past president, Professor Sir Rutherford Robertson, as Deputy Chairman. Professor Badger, an organic chemist, is now a research professor at the University of Adelaide, having recently completed a ten-year stint as its ViceChancellor. $\mathrm{He}$ is firm, persuasive and skilled at the kind of politicking ASTEC needs for success.

While it was officially said that members of ASTEC are not selected as representatives of particular interest groups, it is not hard to see the influence on the present government of the major areas of Australian industry. The rural, steel, mining, chemical, electronics and paper industries all have senior executives on ASTEC, including three managing directors. Just how much time such busy men (there are no women among ASTEC's fifteen members) can devote to the detailed collection and assessment of information across the whole spectrum of science remains to be seen.

In theory, there appear to be few restrictions on ASTEC's coverage of the science and technology scene. The Interim Council's report set itself against covering the social and behavioural sciences, but argued for the inclusion of both the defence and health sciences. In Labor's terms of reference for an earlier Interim ASTEC, social science was in, but defence and health were out. Whether these items will be specified in the legislation is not known as yet. 